\title{
IMPLEMENTASI FINITE STATE AUTOMATA PADA APLIKASI SIMULASI VENDING MACHINE FROZEN FOOD
}

\section{Implementation Finite State Automata on Frozen Food Vending Machine Simulation Application}

\author{
Agung Sudrajat', Windu Gata ${ }^{2}$, Eni Heni Hermaliani ${ }^{3}$, Laela Kurniawati ${ }^{4}$, Frieyadie ${ }^{5}$ \\ Program Studi Ilmu Komputer, Fakultas Teknologi Informasi, Universitas Nusa Mandiri (UNM) Jakarta \\ Jalan Kramat Raya No. 18, Senen, Jakarta Pusat

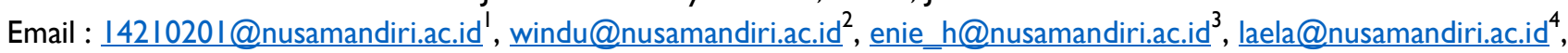 \\ frieyadie@nusamandiri.ac.id ${ }^{5}$
}

\begin{abstract}
ABSTRAK
Frozen food adalah produk makanan yang telah dikemas dan disimpan beku dalam freezer sehingga siap untuk dimasak dan dikonsumsi pada waktu tertentu. Kebiasaan masyarakat kota yang sibuk dengan pekerjaannya menjadikan olahan frozen food sering dijadikan alternatif makanan untuk keluarga di rumah. permasalahan yang ada di masyarakat adalah masyarakat ingin penyajiannya lebih cepat dan praktis serta bisa mendapatkan makanan tersebut dimana saja. Oleh sebab itu kami memberikan rekomendasi implementasi dibuat sebuah mesin otomatis yang bisa menjawab permasalahan tersebut yaitu dengan adanya vending machine frozen food. Pelaksanaan penelitian ini meliputi tiga tahapan diantaranya yaitu perancangan finite state automata (FSA) vending machine frozen food, pengujian finite state automata (FSA) vending machine frozen food dan konsep desain vending machine frozen food. Agar lebih menarik untuk dipandang mata dan mengundang selera makan frozen food kami kemas dalam kemasan bento yaitu menggunakan konsep one dish meal atau hidangan sepinggan yang mengandung gizi yang lengkap. Penerapan konsep FSA pada frozen food vending machine ini dapat menjadi sebuah alternatif dalam membuat rancangan berbagai jenis vending machine.
\end{abstract}

Kata kunci: Finite State Automata, Vending machine, Frozen food

\section{ABSTRACT}

Frozen food is a food product that has been packaged and stored frozen in the freezer so that it is ready to be cooked and consumed at a certain time. The habit of city people who are busy with their work makes processed frozen food often used as an alternative food for families at home. The problem in society is that people want it to be served more quickly and practically and can get the food anywhere. Therefore, we provide recommendations for the implementation of an automatic machine that can answer these problems, namely the existence of a frozen food vending machine. The implementation of this research includes three stages including the design of finite-state automata (FSA) frozen food vending machines, finite state automata (FSA) testing of frozen food vending machines, and design concepts of frozen food vending machines. To make it more attractive to the eye and invite appetite, we pack frozen food in bento packaging, using the concept of a one-dish meal or a plate of food that contains complete nutrition. The application of the FSA concept to this frozen food vending machine can be an alternative in designing various types of vending machines.

Keywords: Finite State Automata, Vending machine, Frozen food

\section{Pendahuluan}

Frozen food adalah produk makanan yang telah dikemas dan disimpan beku dalam freezer, sehingga siap untuk dimasak dan dikonsumsi pada waktu tertentu (Wicaksana, Paramastri, \& Ardyanfitri, 202l). Pada umumnya proses pembuatan produk beku melalui beberapa tahap mulai dari persiapan raw material (bahan baku), proses pencetakan atau forming (untuk produk seperti nugget), pelapisan (coating), penggorengan (frying), pembekuan (freezing) dan pengemasan (packaging). Jika dalam keadaan beku frozen food bisa disimpan dengan jangka waktu yang lama serta tidak mudah basi. Kebiasaan masyarakat kota yang sibuk dengan pekerjaannya menjadikan olahan frozen food sering dijadikan alternatif makanan untuk keluarga di rumah. yang jadi permasalahan adalah masyarakat yang ada di sekitar lingkungan saya ingin penyajiannya lebih cepat dan praktis serta bisa mendapatkan makanan tersebut dimana saja. oleh sebab itu kami memberikan rekomendasi implementasi dibuat sebuah mesin otomatis yang bisa menjawab permasalahan tersebut yaitu dengan adanya vending machine frozen food. agar lebih menarik untuk dipandang mata dan mengundang selera makan frozen food kami kemas dalam kemasan bento yang bertujuan untuk membuat kemasan makanan lebih menarik dan unik (Daryanti \& Puspitasari, 2020).

Terkait dengan vending machine frozen food ini telah dilakukan penelitian sebelumnya, yaitu penelitian 
sebelumnya fokus membahas tentang proses pembuatan model konseptual untuk simulasi proses mengukus frozen food berbahan baku roti. pemodelan konseptual adalah aspek yang paling penting dalam proses simulasi pengembangan model karena akan memberikan pengaruh yang signifikan terhadap kualitas dan efisiensi proyek simulasi (Zainuddin et al., 2009). Dengan kata lain, pemodelan konseptual melibatkan memutuskan cara di mana dunia virtual model simulasi harus bekerja, entitas yang berisi semua interaksi, aturan, dan persamaan yang dapat menentukan perilaku mereka. Dengan demikian, desain model akan memberikan dampak pada semua aspek studi simulasi, khususnya persyaratan data, proses pengembangan kecepatan model, keabsahan model, kecepatan eksperimen dan kredibilitas hasil model. Oleh karena itu, ini menjadi yang paling sulit dan paling tidak dipahami tahap dalam proses pemodelan.

penelitian ini mencoba mengembangkan hasil dari penelitian sebelumnya yaitu dengan menerapkan implementasi FSA (Finite State Automata) pada aplikasi vending machine frozen food bento yang didalamnya ada pilihan nasi, daging ayam, daging sapi, ikan, tempura udang dan ada juga sayuran dan selada yang memiliki kandungan nutrisi, protein dan serat yang dibutuhkan tubuh. bento adalah konsep one dish meal atau hidangan sepinggan yang mengandung gizi yang lengkap. Bento merupakan bekal yang praktis, menarik dan kaya akan gizi yang berguna untuk pertumbuhan, perkembangan serta meningkatkan kecerdasan (Rachmawati, Mufidah, \& Sulistiyani, 2020).

\section{Metode}

Metode penelitian adalah Pelaksanaan penelitian yang meliputi tiga tahapan diantaranya yaitu perancangan finite state automata (FSA) vending machine frozen food, pengujian finite State automata (FSA) vending machine frozen food dan konsep desain vending machine frozen food seperti dijelaskan pada gambar I berikut ini :

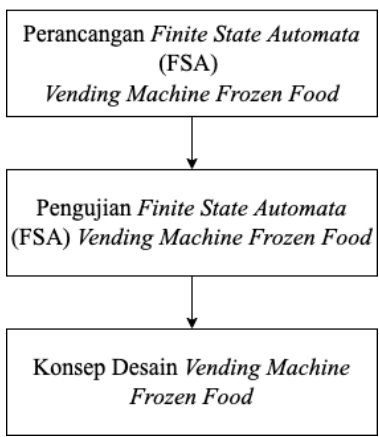

Gambar I Tahapan Metode Penelitian

\section{I Finite State Automata (FSA)}

Finite State Automata adalah mesin abstrak berupa sistem model matematika dengan masukan dan keluaran diskrit yang dapat mengenali bahasa paling sederhana (bahasa reguler) dan dapat diimplementasikan secara nyata (Atina, Palgunadi, \& Widiarto, 2016). Pada tahapan ini, penelitian menghasilkan sebuah rancangan FSA dari sistem frozen food VM berikut diagram transisi dalam setiap tahapan perubahan state mesin, serta output dari mesin VM. Dalam hal penelitian ini, lebih spesifiknya peneliti menggunakan Non-Deterministic Finite Automata (NFA) dengan model Finite Automaton.

\subsection{Pengujian FSA}

Pengujian FSA dilakukan agar prototype vending machine dapat berfungsi dengan baik sesuai dengan tujuan yang diharapkan (Lehman \& Sanjaya, 2017). Pada tahapan pengujian FSA, peneliti menggunakan menggunakan fungsi transisi input dan fungsi transisi output untuk menguji tahapan setiap state dari FSA sehingga dapat dipastikan tidak akan terjadi kesalahan dalam perancangan FSA. pengujian pada penelitian ini menggunakan JFLAP yaitu perangkat lunak untuk bereksperimen dengan topik bahasa formal termasuk automata terbatas nondeterministik, automata pushdown nondeterministik, mesin Turing multitape, beberapa jenis tata bahasa, parsing, dan sistem-L (Rodger, 2018)

\subsection{Desain frozen food VM}

Desain frozen food VM merupakan penerapan dari bidang ilmu Teori Bahasa dan Automata yang dapat menjual barang atau kebutuhan manusia secara otomatis (Wicaksono, Amrizal, \& Mumtahana, 2019). Pada tahapan ini, penulis memberikan gambaran utuh atas desain perangkat keras yang dibutuhkan oleh mesin frozen food, serta gambaran perangkat lunak dari frozen food vending machine.

\section{Hasil Dan Pembahasan}

\section{I Finite State Automata}

Diagram FSA menggambarkan sebuah model yang dapat memperoleh input dan output dengan jumlah state yang berhingga banyaknya serta dapat berpindah dari satu state ke state berikutnya sesuai input yang diperoleh seperti digambarkan pada gambar 2 berikut ini : 


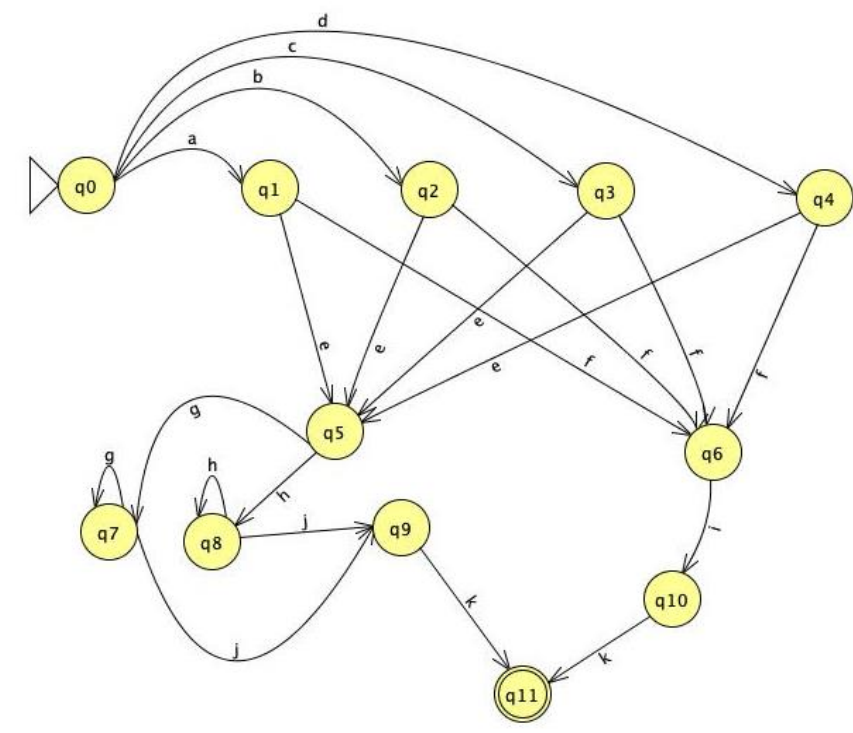

Gambar 2 Rancangan Diagram FSA

Pendefinisian tuple dalam diagram FSA memiliki lima buah tuple (Bukardi \& Pambudi, 20I5), dengan formula sebagai berikut:

$M=(Q, \Sigma, \delta, S, F)$

dengan:

$\mathrm{Q}$ : himpunan state

$\Sigma$ : himpunan simbol input

$\delta$ : fungsi transisi

$S$ : keadaan awal

$\mathrm{F}$ : himpunan keadaan akhir sehingga didapat definisi sebagai berikut :

$\mathrm{Q}:\{q 1, q 2, q 3, q 4, q 5, q 6, q 7, q 8, q 9, q|0, q| I\}$

$\Sigma:\{a, b, c, d, e, f, g, h, i, j, k\}$

$\delta:$ dijelaskan di tabel I

$S: q l$

$F: q l l$

Keterangan :

$\mathrm{q} 0=$ State Awal

ql = Nasi Daging Ayam Sayuran dan Selada

q2 = Nasi Daging Sapi Sayuran dan Selada

q3 = Nasi Tempura Udang Sayuran dan Selada

q4 = Nasi Daging Ikan Sayuran dan Selada

q5 = Pembayaran Tunai

q6 = Pembayaran Non Tunai

q7 = Input Tunai 5000

q8 = Input Tunai 10000

q9 = Total penjumlahan State q7 dan q8

$\mathrm{q} 10=$ Emoney

q I I = Final State
Diagram state tersebut memiliki beberapa masukan spesial untuk pembayaran tunai, yaitu g, dan h, yang menyimbolkan uang tunai Rp. 5.000 dan Rp. 10.000 . Mesin tersebut akan berjalan apabila masukan yang dituju sesuai dengan state yang akan dituju.

Pada state awal, pengguna akan diminta untuk memilih frozen food apa yang diinginkan, misalnya pengguna memilih frozen food nasi daging ayam sayuran dan selada, maka state awal q0, akan menuju ke state ql. Setelah frozen food dipilih maka akan muncul pilihan metode pembayaran, jika menggunakan uang tunai, maka akan menuju ke state q5, sedangkan apabila menggunakan pembayaran e-money maka akan menuju ke state q6. Apabila pengguna memilih pembayaran e-money maka akan diminta untuk melakukan tap kartu e- money menuju state ql0 dan setelah itu frozen food yang telah dipilih akan keluar. Namun, jika pengguna memilih menggunakan uang tunai, maka pengguna akan diminta memasukkan uang. Jika pengguna memilih memasukan uang Rp. 5.000, maka akan menuju ke state q7, jika pengguna memilih memasukkan uang Rp. 10.000 maka akan menuju ke state q8. Kemudian kedua state, q7 dan q8 akan di jumlahkan sehingga menuju ke state q9. Setelah itu frozen food yang telah dipilih akan akan keluar ke qll.

\subsection{Pengujian}

Pengujian FSA dapat dilihat pada fungsi transisi pada tabel I yang memberikan gambaran alur proses yang terjadi pada sistem frozen food vending machine dengan menerapkan prinsip FSA. Pengujian input string pada diagram FSA dilakukan dengan menggunakan software JFLAP versi 7.I(Dougherty, Garcia, Horton, \& Rodger, 2004). Mesin atau sistem akan mengikuti alur dari proses pembelian frozen food melalui vending machine. Fungsi transisi tersebut dapat memastikan tidak akan terjadi kesalahan dalam proses pembelian sesuai yang diinginkan pengguna. FSA digunakan untuk membaca simbol masukan yang diberikan dari state awal sampai berakhirnya proses sehingga diperoleh suatu bahasa yang dikenali oleh sistem vending machine. 
Tabel I Fungsi Transisi Input ( $\delta$ )

\begin{tabular}{cccccccccccc}
\hline$\delta$ & $\mathrm{a}$ & $\mathrm{b}$ & $\mathrm{c}$ & $\mathrm{d}$ & $\mathrm{e}$ & $\mathrm{f}$ & $\mathrm{g}$ & $\mathrm{h}$ & $\mathrm{i}$ & $\mathrm{j}$ & $\mathrm{k}$ \\
\hline $\mathrm{q} 0$ & $\mathrm{ql}$ & $\mathrm{q} 2$ & $\mathrm{q} 3$ & $\mathrm{q} 4$ & - & - & - & - & - & - & - \\
$\mathrm{ql}$ & - & - & - & - & $\mathrm{q} 5$ & $\mathrm{q} 6$ & - & - & - & - & - \\
$\mathrm{q} 2$ & - & - & - & - & $\mathrm{q} 5$ & $\mathrm{q} 6$ & - & - & - & - & - \\
$\mathrm{q} 3$ & - & - & - & - & $\mathrm{q} 5$ & $\mathrm{q} 6$ & - & - & - & - & - \\
$\mathrm{q} 4$ & - & - & - & - & $\mathrm{q} 5$ & $\mathrm{q} 6$ & - & - & - & - & - \\
$\mathrm{q} 5$ & - & - & - & - & - & - & $\mathrm{q} 7$ & $\mathrm{q} 8$ & - & - & - \\
$\mathrm{q} 6$ & - & - & - & - & - & - & - & - & $\mathrm{q} 10$ & - & - \\
$\mathrm{q} 7$ & - & - & - & - & - & - & - & - & - & $\mathrm{q} 9$ & - \\
$\mathrm{q} 8$ & - & - & - & - & - & - & - & - & - & $\mathrm{q} 9$ & - \\
$\mathrm{q} 9$ & - & - & - & - & - & - & - & - & - & - & $\mathrm{qll}$ \\
$\mathrm{q} 10$ & - & - & - & - & - & - & - & - & - & - & $\mathrm{qll}$ \\
$\mathrm{q} 11$ & - & - & - & - & - & - & - & - & - & - & - \\
\hline
\end{tabular}

Pengujian input string pada mesin dilakukan dengan menggunakan aplikasi JFLAP. Pada tabel 3 disajikan contoh beberapa string berupa kombinasi karakter masukan berikut dengan hasil keluaran akhir dari mesin saat dilakukan pengujian FSA pada aplikasi JFLAP.

Tabel 2 Pengujian masukan string dan keluaran akhir

\begin{tabular}{ll}
\hline Masukan String & Keluaran Akhir \\
\hline aegjk & Nasi Daging Ayam \\
Sayuran dan Selada & Nasi Daging Ayam \\
aeggjk & Sayuran dan Selada \\
Nehjk & Nasi Daging Ayam \\
& Sayuran dan Selada \\
aehhjk & Nasi Daging Ayam \\
& Sayuran dan Selada \\
afik & Nasi Daging Ayam \\
& Sayuran dan Selada \\
begjk & Nasi Daging Sapi Sayuran \\
& dan Selada \\
beggjk & Nasi Daging Sapi Sayuran \\
& dan Selada \\
behjk & Nasi Daging Sapi Sayuran \\
& dan Selada \\
behhjk & Nasi Daging Sapi Sayuran \\
& dan Selada \\
bfik & Nasi Daging Sapi Sayuran \\
& dan Selada \\
cegjk & Nasi Tempura Udang \\
& Sayuran dan Selada \\
ceggjk & Nasi Tempura Udang \\
& Sayuran dan Selada \\
cehjk & Nasi Tempura Udang \\
& Sayuran dan Selada \\
\hline &
\end{tabular}

\begin{tabular}{ll}
\hline Masukan String & Keluaran Akhir \\
\hline cehhjk & Nasi Tempura Udang \\
& Sayuran dan Selada \\
cfik & Nasi Tempura Udang \\
& Sayuran dan Selada \\
degjk & Nasi Daging Ikan Sayuran \\
& dan Selada \\
deggjk & Nasi Daging Ikan Sayuran \\
& dan Selada \\
dehjk & Nasi Daging Ikan Sayuran \\
& dan Selada \\
dehhjk & Nasi Daging Ikan Sayuran \\
& dan Selada \\
dfik & Nasi Daging Ikan Sayuran \\
& dan Selada \\
\hline
\end{tabular}

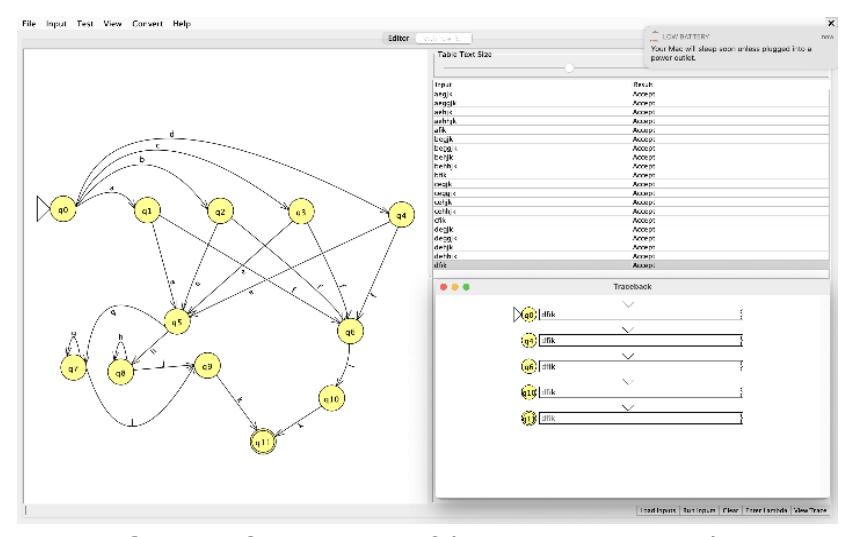

Gambar 3 Pengujian FSA pada aplikasi JFLAP

Gambar 3 menunjukkan proses pengujian FSA dengan contoh input string sebagai berikut pada mesin, sehingga proses yang terjadi adalah sebagai berikut:

Tabel 3 Pengujian masukan string dan keluaran akhir

\begin{tabular}{lc}
\hline \multicolumn{1}{c}{ Masukan String } & Keluaran Akhir \\
\hline aegjk & accept \\
aeggjk & accept \\
aehjk & accept \\
aehhjk & accept \\
afik & accept \\
begjk & accept \\
beggjk & accept \\
behjk & accept \\
behhjk & accept \\
bfik & accept \\
cegjk & accept \\
ceggjk & accept \\
cehjk & accept \\
cehhjk & accept \\
cfik & accept \\
degjk & accept \\
\hline
\end{tabular}




\begin{tabular}{lc}
\hline \multicolumn{1}{c}{ Masukan String } & Keluaran Akhir \\
\hline deggjk & accept \\
dehjk & accept \\
dehhjk & accept \\
dfik & accept \\
\hline
\end{tabular}

Demikian juga dengan pengujian FSA menggunakan string sebagaimana tercantum pada tabel 3 menunjukkan hasil yang konsisten sesuai fungsi transisi input dan output sebagaimana tercantum pada tabel I dan tabel 2 .

\subsection{Desain Frozen food Vending machine}

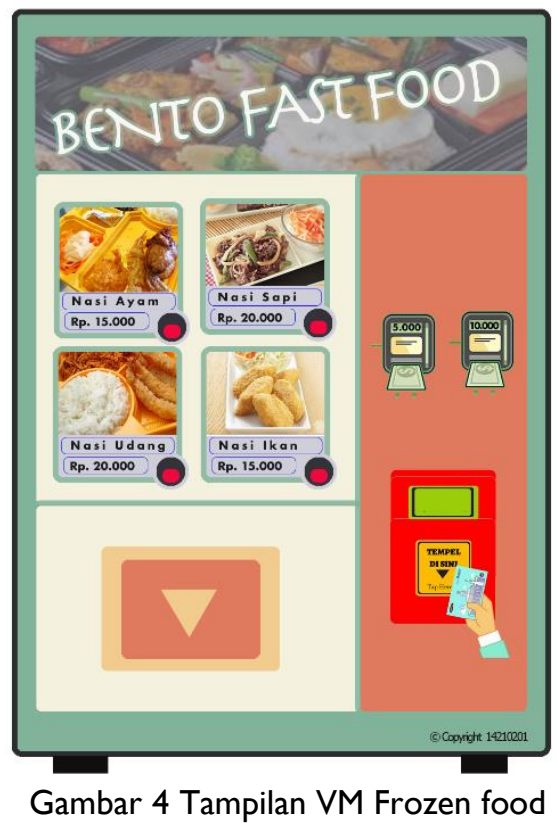

Pada VM Frozen food ini akan ditampilkan 4 jenis makanan bento yang dapat dipilih oleh pelanggan. pada gambar 4 ditampilkan bahwa mesin dapat menerima masukan uang dengan nominal Rp. 5.000 dan Rp. 10.000 serta mesin dapat menerima masukan e-money dengan cara menggunakan tempel kartu pada tempat yang telah disediakan. langkah pertama yang dilakukan oleh pembeli adalah dengan memilih jenis makanan bento mana yang akan dibeli, apabila sudah ditentukan pilihan tekan tombol yang ada pada bagian bergambar menu makanan kemudian mesin menghitung jumlah harga yang harus dibayar oleh pembeli. kemudian pembeli akan diberi dua pilihan pembayaran yaitu apakah ingin menggunakan pambayaran tunai atau pembayaran non tunai apabila pembeli memilih pembayaran tunai maka pembeli memasukan uang kertas Rp. 5.000 atau Rp. 10.000 kedalam VM sesuai total harga yang harus dibayar maka otomatis VM melakukan validasi apakah uang tunai yang dimasukan telah sesuai dengan harga yang harus dibayar atau tidak apabila sesuai maka mesin akan mengeluarkan jenis makanan bento yang dipilih. pilihan pembayaran yang kedua adalah pembeli bisa melakukan pembayaran non tunai dengan menggunakan kartu e-money, ketika pembeli telah menentukan pilihannya maka pembeli melakukan tempel kartu e-money ada area yang telah ditentukan atau di gambar 4 dituliskan tempel di sini maka mesin otomatis akan melakukan validasi pembayaran dengan cara membaca kartu dan apabila telah sesuai maka VM akan mengeluarkan jenis makan yang telah dipilih sebelumnya.

\section{Simpulan Dan Saran}

FSA dapat dijadikan sebagai acuan dasar dalam mengembangkan frozen food vending machine, dengan lima buah tuple, sebelas state, sebelas input, dan empat output, serta dengan fungsi transisi input dan transisi output yang berhasil menerima berbagai string input.

Penerapan konsep FSA dalam mesin frozen ini digambarkan dengan cara FSA membaca setiap simbol input yang diberikan kepada mesin sebagai sebuah bahasa yang dapat dikenali oleh sistem. Mesin kemudian akan mengeluarkan output berupa makanan sesuai dengan pilihan dan jumlah uang yang dimasukan kepada mesin.

Penerapan konsep FSA pada frozen food vending machine ini dapat menjadi sebuah alternatif dalam membuat rancangan berbagai jenis vending machine. Selain itu hasil penelitian ini dapat lebih lanjut dikembangkan untuk menerima input pembayaran lebih banyak seperti gopay, ovo, dana dll.

\section{Pustaka Acuan}

Atina, V., Palgunadi, S., \& Widiarto, W. (2016). Program Transliterasi Antara Aksara Latin dan Aksara Jawa dengan Metode FSA. Jurnal Teknologi \& Informasi ITSmart, I(2). https://doi.org//0.2096I/its.vli2.592

Bukardi, E. S., \& Pambudi, W. S. (20I5). Perancangan dan pembuatan Semi Automatic T-Shirt Folding Machine Menggunakan Metode Fuzzy Proportional Derivative (FPD). Jurnal Sains Dan Teknologi, I(I).

Daryanti, M. S., \& Puspitasari, E. (2020). Pelatihan pembuatan makan bento pada ibu-ibu pkk di Botokenceng Wirokerten Banguntapan Bantul. JURNAL INOVASI ABDIMAS KEBIDANAN (JIAK), I(I). https://doi.org/l0.32536/jpma.vlil.68

Dougherty, J. P., Garcia, D. D., Horton, T. B., \& Rodger, S. H. (2004). Panel on teaching faculty positions. SIGCSE Bulletin (Association for Computing Machinery, Special Interest Group on Computer Science Education), 36(I). https://doi.org/10.1 145/1028/74.97/382

Lehman, A. S., \& Sanjaya, J. (2017). Perancangan Mesin Penjual Makanan Ringan Otomatis. SEMNASTEKNOMEDIA 20I7, 2.6-13. Yogjakarta: 
Universitas AMIKOM Yogyajarta. Retrieved from https://ojs.amikom.ac.id/index.php/semnasteknomedi a/article/view//805

Rachmawati, E., Mufidah, L., \& Sulistiyani, T. (2020). Pelatihan Pengolahan Bento untuk Meningkatkan Kreativitas Menciptakan Bekal Makanan. Abdimas Dewantara, $3(1)$. https://doi.org//0.30738/ad.v3il.6903

Rodger, S. H. (2018). JFLAP. North Carolina: Department of Computer Science, Duke University, Durham, NC.

Wicaksana, W. R., Paramastri, B., \& Ardyanfitri, H. (202I). Purchase Intention Produk Frozen food Berdasarkan Perceived Quality Dan Price Fairness. Jurnal Manajemen Dan Inovasi (MANOVA), 4(I). https://doi.org/10.15642/manova.v4il.382
Wicaksono, T. H., Amrizal, F. D., \& Mumtahana, H. A. (2019). Pemodelan Vending machine dengan Metode FSA ( Finite State Automata ). DoubleClick: Journal of Computer and Information Technology, 2(2), 66-69. Retrieved from http://ejournal.unipma.ac.id/index.php/doubleclick

Zainuddin, F., Ali, N. M., Sidek, R. M., Romli, A., Talib, N., \& Ibrahim, M. I. (2009). Conceptual modeling for simulation: Steaming frozen food processing in vending machine. Proceedings - 2009 2nd IEEE International Conference on Computer Science and Information Technology, ICCSIT 2009. https://doi.org// 0.I I09/ICCSIT.2009.5234834 